\title{
THE SOCIO-ECONOMIC EFFECTS OF DIVORCE ON CHILDREN IN WORETA CITY ADMINISTRATION, ETHIOPIA
}

\author{
NEGA GEDEFAW AGMASE* \\ Department of Criminology and Criminal Justice, School of Sociology and Social Work, College of Social Science and the Humanities, \\ University of Gondar, Ethiopia. Email: negagedefaw@gmail.com
}

Received: 16 February 2021, Revised and Accepted: 23 March 2021

\section{ABSTRACT}

Objective: This study attempted to investigate the socio-economic effects of divorce on children in the Woreta City Administration.

Methods: Qualitative, specifically phenomenological research design was employed for understanding the lived experiences of children from divorced families. Data were collected from children of a divorced family and experts through in-depth interviews, focus group discussions, and key informant interviews and participants of the study were selected by using a non-probability of snowball sampling technique. The collected data analyzed and interpreted thematically to address the aforementioned objectives.

Results: The study shows that many children are negatively suffering from the social effects of divorce. This is often expressed by the feeling of insecurity, educational failure and/or low school performances, loss of attachment as well as abuse and neglect. The study further reveals that children are also facing the harmful economic effects of divorce. Inability to access resources to fulfill basic needs, in-accessed to health-care services, as well as learning difficulties and low school performances are the major economic problems of divorce on children.

Conclusion: The study concluded that even if divorce affects all of those involved in its process but it has harmful effects on children's socio-economic wellbeing than others.

Keywords: Socio-economic effect, Divorce, Children, Woreta City Administration.

(C) 2021 The Authors. Published by Innovare Academic Sciences Pvt Ltd. This is an open access article under the CC BY license (http://creativecommons.org/ licenses/by/4.0/) DOI: http://dx.doi.org/10.22159/ijss.2021v9i3.40762. Journal homepage: https://innovareacademics.in/journals/index.php/ijss

\section{INTRODUCTION}

The Essential English Dictionary [1] explains divorce as legal permission to break away one's married partner and to marry somebody else if so desired, or to officially end a wedding. At present, the breakdown of the family is one of the foremost prevailing societal problems arising from the disagreement and disputes of spouses that would either be deemed as complex and grave or minor. It is believed that the worth attached to children, infertility is usually considered a crucial explanation for marriage instability and/or divorce in many African populations [2]. From the findings in Ethiopia, the bulk of the woman who did not have a child within their first marriage divorced within 20 years, and 85\% of those women make divorce within the primary 5 years of their first marriage [3]

The effect of divorce is that the plight of the children. The children become the foremost vulnerable group after divorce. The family which is the first agent of socialization exists no more; this circumstance makes nurturing teenagers difficult. Prostitutes, armed robbers, and other social misfits are normally found to be the many children from broken homes. Things become worst when children shuttle between both parents' homes; a parent always believes the kid is with the opposite parent even the kid is elsewhere [4]. The consequences of divorce are irreversible harm to all or any involved within the process, but critical to the children. When children have gotten less attention, receive less emotional support, financial assistance, and practical help for tutorial support and encouragement they will lose stimulation of socialization; resulting decrease in arrogance, affection, and social maturity of the children [5]. After their parents' divorce, unfortunately, children received less attention from parents once they might face school dropout, faced hunger, shortage of clothing, feeling guilty, and depart from peers [6].
Divorce has had a profound impact on the economic well-being of children and women, but they also appear to have consequences for children's afterward life [7]. Divorce is a key life-course risk that typically has significant economic consequences, as well as possible negative effects on health and well-being [8]. Children typically suffer greater disadvantages, such as declines in financial well-being, as a result of parental separation [9]. The economic problem is serious and has negative impacts on children's wellbeing; security in the economy is essential to be well socially, psychologically, and emotionally. Parental divorced children have faced clothing problems, suffered from food shortages, and financial constraints for educational expenses and entertainment [10].

Some studies are conducted in Ethiopia that focused on the issue of divorce from different vantage points. For instance Tarekegn, [11], Kifle [12], Abebe [13], Serkalem [14] Astere [10], and Seid and Yemataw [15] conducted research regarding divorce. However, most research as indicated is based on the causes of divorce. Relatively little is concerned with the effects of divorce and even less in seeking to concern with the socio-economic effects of divorce on children. This study focused on the socio-economic effects of divorce on children. Since Woreta City Administration is one of the foremost susceptible areas of the socio-economic and other effects of divorce, especially on children. Because the recorded data of the Court in four consecutive years from 2016 to 2019 G C., 475, 540, 539, and 514, respectively, implies that the matter is just too high. Therefore, the majority of the recorded divorce cases also indicate people make divorce after they need to get the birth of a Childs (Fogera Wereda court, 2019). As well; the rationale for the choice of this topic and study area is also embedded in the researcher's practical experience. During 1 year of working experience as a social worker at the Woreta project of justice for children, the researcher dealt with several divorce cases. The question arose about why some 
divorces were extremely painful for children beyond the divorcees, especially in socio-economic wellbeing. Since no matter, which one of the causes is the fundamental cause of any divorce, that the divorce phenomenon affects the social and economic well-being of the whole family members, however, its effect is stronger and harsh to children than others.

\section{Study objectives}

The general objective of the study is to assess the socio-economic effects of divorce on children in Woreta City Administration.

\section{Specific objectives}

The specific objectives are as follows:

- To investigate the social effects of divorce on children.

- To examine the economic effects of divorce on children.

\section{METHODS}

\section{Study design and approach}

For this study purely qualitative research approach was employed; hence, it provides rich data about the real life of children from divorced families and their living situations because it seeks to answer questions framed with what and how of a given phenomenon. Moreover, it is a way of exploring perceptions, behaviors, attitudes as well as experiences of children through the technique of in-depth interview [16]. Furthermore, this research approach involves an interpretive, naturalistic approach to the world and it makes the researchers study things in their natural setting, attempting to make sense of, or interpret, and phenomena in terms of the meanings children bring to them [17]. Therefore, the very nature of studying the socio-economic effects of divorce on children required a qualitative research approach to deeply understand their experiences. Along with the qualitative approach was follow a phenomenological design in that it has given great emphasis to the lived experience of children from divorced families. Thus, this design enabled the investigator to assess the socio-economic effects of divorce on children. Hence, the possibility of understanding the lived experiences marks phenomenology used as a design because the procedure involves studying a small number of subjects through extensive and extended engagement.

\section{Data collection methods}

Based on the objectives of the study, the most important data collection methods such as in-depth interviews, focus group discussions (FGD), and key informant interviews were employed since these methods may enable the researcher to assure the validity of the study.

\section{In-depth interview}

For this study, in-depth interview was conducted with children from divorced families and the size of the interviewee was 14 as it was decided based on data saturation. In-depth interviews are the type of interviews that are designed to discover essential motives, as well as desires and, are often used in motivational research hence such types of interviews are held to explore the needs, desires, and feelings of children. Hence, in this study, the semi-structured interview was employed because using this type of data collection method allows the researcher to interject where necessary and ensure that the subject understands the topic or question under scrutiny. Moreover, it makes the interviewer be prepared and appear competent during the interview as well; it allows their freedom to express their views on their own terms. It also helps the researcher to address the phenomena profoundly through a space of aperture for the children to express their experiences in detail [18].

\section{FGD}

FGD was conducted with children from divorced families and as it is recommended that conducting FGD with two to three group discussions for a small project or small study, this study collected data on two groups with eight participants. The ground to the choice of this data collection method is that it used to access the views of a minority or disadvantaged groups, such as women, children, or people with disabilities [19].

\section{Key informant interviews}

Key informant interviews were conducted from experts of the office of women and children's affairs, court judges, project of justice for children, solicitors, and the prosecutor of Justice Office through interviewing them and based on this the size of key informants were five. The ground of this method is that, to gather information about the issue from a person's unique professional background related to the subject since it enables the researcher to obtain vital information about the socio-economic effects of divorce on children. Consequently, the method was to help to gather in-depth information on the practical experiences and efforts done by the concerned bodies toward the socioeconomic effects of divorce on children.

\section{Data collection procedure and sampling technique}

The researcher had prepared the guide questions and translated them from English to Amharic version which is the local as well as the working language of participants and or informants since it was helped participants to understand the issue easily and to avoid the interpretation of the conversation flow due to translation problems. Then, the researcher was contacted with children from divorced parents in their living and working place and proceeded to explain the rationale as well as the purpose of the study to get their consent. And then, a non-probability of snowball sampling technique was selected since in the case of snowball sampling the researcher samples initially a small group of children's relevant to the research questions, and these sampled children's proposed other participants who have had the experience or characteristics relevant to the research and these selected participants then suggested others and so on [20].

\section{Data quality assurance and procedures of data analysis}

The researcher carefully selected the participants of the study those who have been too relevant based on the outlined inclusion criteria, and to get detailed and accurate data participants were interviewed in an appropriate place and time. Because the main threat of qualitative research is participant and researcher bias as well as reactivity. As well; in this study, the data that were gathered from different sources using different data collection methods have been analyzed and interpreted thematically. Since thematic analysis is a method of analyzing qualitative data and more relevant in phenomenological research. Because the researcher closely examined the data to identify common themes, topics, ideas, and patterns of meaning that come up repeatedly; reviewing themes, defining, and naming themes [21].

\section{Ethical consideration}

Finally, the researcher has conducted the study by taking all relevant considerations or standards of research ethics such as not-harm, confidentiality, and voluntarism in the course of this study for children's needy of protection, safety, and rights. Since, in doing research, human subjects must be treated with dignity, fairness, and respect. Hereof, the purpose of the study and the manner in which the data were handled was explained to the actors that were directly or indirectly concerned and or involved with the issue under the study. During the individual interviews, the researcher has been given time to the children to talk about their feelings and perceptions. Participants were briefed about the subject before the research commenced. Permission and/or all ethical clearance were obtained from the concerned ethical clearance office of the University of Gondar as needed.

\section{RESULTS}

\section{Social effects of divorce on children}

This study indicates that social effect is one of the major effects that children have encountered following their parents' divorce. Therefore, the finding mainly indicated abuse and neglect, loss (loss of attachment); education and/or low performance in school as well as insecurity are the major social effects of divorce.

\section{Abuse and neglect}

The results of the study show that abuse and neglect are one of the main consequences of parental divorce on children. In this regard, 17-year- 
old child from divorced parents articulated how abuse and neglect affect his social life as:

My parents divorced when I was a kid. In fact, even before they were divorced, my father was an alcohol-addicted man and who would not care for me. Instead, he told me that my end would not be beautiful and that I could be a bad boy. Unfortunately, my parents died sometime after their divorce. After all, everyone serves me, bullies me, and people refuse to let me participate in their social lives. You know, no one gets up and insults me for no reason, and neighbors and other local peoples have started to hate me instead of love. And they think that such a child is useless, and will never be successful in the end.

As we can understand from the above narrations, child abuse, harm, and stigma begin with their parents and families. Moreover, it is very likely that a family that cannot be a role model for children and who have a bad attitude is more likely to break up. Furthermore, because of divorce, children are more likely to be marginalized, insulted, abused, and exposed to other harms.

In this view, FGD discussants reported it as:

The locals often treat us as thieves, gangsters, unhealthy people, and bullies. Just because they know we have no family supervision and control, they think we are not good people. Our social relationships and living with the local community are also low, they will not allow us to join them and exclude us from everything. There are also some who do not consider us as human beings and those who forced to work without payment, they force us to arrest us if they need to, and they can beat us if needed.

What's more, one of the key informants of the study briefly explained how much children from divorced families are abused and neglected in the community as:

Children from divorced parents are discriminated against in the community and are excluded from the community because they have been named once a child of a divorced parent. They are considered useless and as a result, they do not get what they deserve in the community, nor do they use the things they need to use. They are not as involved with the community as the other children, who live with both of their parents. These children are excluded and isolated from accessing and utilizing the basic social needs which are prescribed in formal and informal institutions within the community. They are less likely to grow slime water with their friends, spout soil, playing football, and laughter because people do not want these children to join their children. Generally, it is difficult to take the social life of these children as life, and we can call them lonely in the community because they live in the community, but they are largely marginalized and do not get the social services that any child or man should have. Besides, these children are vulnerable to various types of violence, especially girls, who are more likely to be raped by their stepfather, employers, teachers, or other people.

Therefore, the above excerpts indicated that children from destructed families are significantly more exposed to child abuse and neglect than children from intact families because of divorce. As we know parents are the most crucial social units who are highly responsive to care for their children and make them safe with the community. But due to parent's divorce, they are more likely to be ignored by the majority part of the society, they are suffered from abuse (physical abuse, sexual abuse, verbal abuse...) and neglect as well as loneliness. The majority of children from divorced families are abused and forced to leave home by step-mothers and step-fathers. For the reason that, abuse and neglect make their social life very low as well as difficult, and they are exposed to different social problems and more likely to develop anti-social behavior and hostility for society.

\section{Loss (loss of attachment)}

As the research result indicated that loss is one of the main social effects of divorce on children. Even one of the most outcomes of divorce on children is that the children from divorced families are angrier and have a poorer bond with both their parents and relatives as well as with the community. In this point of view a 17-year-old child express how the loss of attachment affects his social life in the community as:

I am very against divorce... not so much superior anymore because as I think so all divorced parents are not good in terms of attachment with me for the reason that as I think my relationship was serious and only with my parents. But now it is failed and I fear getting into relationships with my dears, on the street as well as in the community. So, no one is eager to make an attachment with me and it diminished my motivation for everything because I lost my parent's attachment due to divorce.

As we can understand from the above data that parental divorce has a negative effect on children in terms of attachment. That is, children think that they have a good and close relationship and that it is only with their parents. The most powerful thing here is, once parents get divorced, children find it difficult to form attachments and relationships with their peers or with other local people. They will become cowards, they will feel hated and disgusted in general, and it will play a very important role in the social stigma and harm that they do with their relationships.

Furthermore, the above situation also supported by the assertion explained by the key informant interview as:

A child should grow in a healthy and functioning relationship with a sensitive and responsive adult whom the child perceives to be his or her parents. But children from broken parents are not lucky to get proper attachment, love, care, attention, and commitment between family members. Because so as to provide the environment for their healthy development and they lost their proper attachment and relationship because of their parents' divorce.

As a result, the above finding demonstrated that loss or loss of attachment makes children from a divorced families disadvantaged of the opportunities to have a good attachment, love, commitment, and care. Children need loving care and attention if they are to develop into productive adults with the ability to have safe, nurturing, and lasting relationships because a good relationship brings safety, comfort, soothing, and pleasure for them. However, children from divorced families did not well cared for and did not have a special form of relationship especially characterized by the maternal-child relationship because of parents' divorce.

The social effects of divorce on the education and academic performances of children

Another widespread finding of the study was regarding education and school performances of children from a divorced family. In this regard, a 14-year-old child from divorced parents explained the phenomena as: Of course, I was a good student while I was with my mother, but I dropped out of school last year because my mother got married and moved away. Of course, my mother wanted to take me away when she left the city, but her husband refused to let me live with them. That's why I decided to continue my education while living on the street. But I can't imagine learning and being successful while living on the streets, because I face so many obstacles. You know, even if I earn some money for school, being a kid especially from a divorced family has its own effects because I need someone to help and take care of me but no one to do it. Even when there is a parental ceremony at school, and there was no one who would be available to me. And my interest in education began to diminish, I began to miss school, and then my grades began to decline, and I gradually quit school.

It can be understood from the narrative above that while some of the divorces of parents can create positive opportunities for children to be successful in their studies; most divorces are more likely to have a negative effect on children because children need rigorous parental supervision and follow-up to be successful in their education. They can get this supervision only when the children are living with both biological parents. Because if parents do get a divorce, it means they 
are less likely to take on such responsibility. And so, these children are more likely to miss school, have poor grades at school, and drop out of school.

Furthermore, one key informant explains the educational condition of children from divorced parents as:

The children whose parents are divorced are often more likely to be poorly educated than their friends or other children who are living with both of their parents. Children have the right to education, parental supervision, and care, but even though these rights play an important role in the success of children's education, children who lose their parents due to divorce lose these rights as well. As it turns out if children do not receive parental supervision and no one closely monitors them, they will drop out of school, increase school absences, develop bad behavior and these children are more likely to miss school.

The data above demonstrated that by and large children of divorce are unhappy and have more problems in education than their relatives. Divorce has a negative effect on the education of parental divorced children and children's academic performance is lower, some of them are enrolled in school or as a maximum the same as before. In general, children from divorced families today are faced with many difficulties and challenges including what group to associate with within the school, how to deal with certain peer pressures that arise, and what path to take after school, and so on.

\section{Insecurity}

Children from divorced families are one part of the society and their well-being is critical for the survival of the society as well as its orderly functioning so that they are at risk of, subject to abuse, violence, neglect, or deprivation from the parent or family care and other un-protective environments. And protecting children from the above risks as well as problems is a function primarily performed by parents and or family. Therefore, children from broken families are easily exposed to the problem of insecurity due to their parents' divorce.

Regarding this 14 years, old child of divorced parents explained it as: I am 14 years old and I live on the street because I lost my parents due to divorce. Everyone in the community considered me as an orphan as well as a child without advocacy and I face challenges of exclusion as well as persecution. You know, no one else to give protection and care for me and people know this so that when I roll to sell gum, biscuit and the like at night or maybe at the day they snatch my money what I have been collected through difficult conditions and if I plead them to spare it they bulldoze by dagger and or beating me.

The above excerpt is easy to understand that children from divorced families are not as safe as the children of intact parents. As we know, parents need to do their part to keep a close eye on their children and to make them safer. For this to happen, the parents' marriage must be protected because the children have neither the power nor the knowledge to protect themselves from various dangers and risks. And it means that these children are more likely to be exposed to a variety of threats, accidents, and hurts. Furthermore, if they are from broken families they would often be on the streets, so their lives would be filled with insecurity and fear. This also exacerbates the vulnerability of the children to various attacks including different abuses.

Likewise, FGD discussants reported it as;

We do not have any security guarantees for children who have lost their parents due to divorce. Everyone can get up, insult us, or even abuse us and forcing us to do hard work without payment. Our parents, too, are not worried about our safety after they have got another marriage. And when we live on the street, we get beaten and harassed, you know, we just live in fear and misery.
In addition, one key informant explained the effect of parental divorce on children's security and well-being as:

Children who have lost their parents due to divorce are not secured. These children are more susceptible to various problems and dangers, including sexual abuse, especially girls who can be raped by their stepfather, easily infected by various diseases, people can use these children forced to theft, force them to steal and beg. This is because these children are not likely to be protected primarily from a variety of risks and threats, because of the loss of parental protection and care.

The above data from FGD discussants and key informant interviews indicated that insecurity is one of the major social effects of divorce on children as they are a high level of vulnerability to different problems and risks. Children's desire to prop up their self-esteem often drives them to seek approval anywhere they can find it. For this reason, Child protection involves preventing and responding to children to specific situations where children are at risk and/or subject to different problems and threats such as abuse, violence, and torture because children have the right to protection from all forms of violence including physical abuse, neglect, and/or negligent treatment (CRC, A/19). With a view to ending these problems and threats or removing children from abusive situations and securing those children's by doing full integration to their family or parents, or at least adjusting them to other protective environments can be met and protected. Many children from divorced families experience separation and anxiety; some of them trays deny their insecurity while others are still suffering.

\section{The economic effects of divorce on children}

As the finding of this study indicated that children from divorced families are more likely to suffer from a variety of negative economic effects such as lack of basic needs including food, shelter and cloths, lack of finance for health care services, lack of school supplies and difficulty attending school.

\section{Lack of income to access to fulfill basic needs}

Lack of income to access basic needs is one and the dominant economic effect of divorce on children. Regarding the negative economic effect of divorce on lack of access to basic necessities 17 years old, the child explains the condition as:

You know, I suffer from hunger many times and I often beg leftovers from hotels and restaurants. Sometimes there are days when I do not get leftover and I drink benzene to relieve my hunger but I do not get it too often but when it is available, I mean it will be a treat for cold and hunger. I live on the street and I also live on the porch because there is no house to sleep in and the cold is very heavy. My life is too hard because I lost my parents first in divorce and later died. It's amazing, I mean now I am 17 but I've never had a shoo-in my life because I have no money to buy it and no one can buy it for me. Of course, there is one person who tries to help me financially but I often use the money that he gives to buy food because my left arm is ailing and I can't work what I want. And finding adequate food, clothing, and shelter is the hardest thing for me.

As can be seen from the data above, divorce has is a disastrous result to children being involved in the process. What we need to understand from this is that when people or parents make a divorce, they are more likely to be harmed themselves by its economic consequences. If the parents' economy is weakened by a divorce, it would mean that they will be less likely to take responsibility for their children. In addition, the parents themselves are exposed to a variety of problems and risks and it is also possible to imagine the possibility of losing their lives. Children also need a parent or close caregiver who can meet their basic needs: Food, clothing, and shelter because these children cannot have the capacity to meet their own basic needs.

More to the point, FGD discussants explained access for basic needs of children from divorced parents as:

We children who are from divorced families are on the street where we spend at least a day or all of our time. Because people have always 
called us children of a divorced parent, they are often marginalized and oppressed us in the society, and they believe that just like everyone else, they do not deserve the basic necessities of food, shelter, and clothing. And no one is on our side to help us and meet our basic needs.

It can be understood from the above data that divorce is often caused by the fact that children suffer from basic needs such as a shortage of food, clothing, and shelter. Furthermore, it can understand that the problem of these children is that not all of the community peoples are capable of helping the children who are living in the community, rather than the abuse and discrimination of those who claim to be the ones who are labeled the children of a divorced parent. There are no governmental or non-governmental institutions and organizations that can help to supplement the basic needs of these children from divorced families and street children in the city.

As well; one key informant elucidated the accessibility of basic needs for children from broken families as:

It is certain that children from divorced parents will have financial difficulties to meet their basic needs because they do not receive the financial support they need from their parents properly and always. These children do not have malnutrition, they have problems with clothing and shelter because they do not have a body of support and have not the age group that can meet their needs support to work on their own. And this economic crisis is affecting children's lives in different ways. Thus, economic life occupies a large part and can have a major impact on social and other aspects of life. Since the local population is unwilling to help these children, the children are at greater risk for pneumonia, hunger, and torture.

For that reason, the above finding shows that the provision of basic needs such as shelter, clothing, and food for children from divorced families is very low and most children from divorced families are under the worst economic conditions. Divorce can significantly reduce the financial power of both parents and or family since they lost a lot starting from the process of divorce to the end. Consequently, children are more exposed to different economic problems such as lack of money to access basic needs (cloth, shelter, and food) and increase in the price of basic needs as well as the breakdown of their either extended or nuclear families as well; they are not in range of working class to be able to generate enough income from their own.

\section{The economic effects of divorce on children's education}

Findings from study participants indicated that learning difficulty is one major economic effect of divorce on children. On the topic of these 16 years old child described it as:

I dropped out of schooling from grade 4 because of a lack of financial support to fulfill necessary educational materials. My mother engages in selling beer and weed. So far her income couldn't support the family. So I decided to drop my learning to involve in wage labor. The income is used as a complementary for household consumption. I was thinking to attend my education at night but the income is not adequate enough for educational expenses and there are some days I passed without a job. I give priority to basic needs such as food consumption and cloth than education to support my mother and younger sister. I am dedicated to helping my younger sister in her education because she is a clever student than me and I know that my mother has substantial hope for her education.

As we can see from the data above, one of the most important negative effects that children are encountered due to their parents' divorce is that their education is at risk. The findings of the study show that parents are often advised to grow up children with a mother after a divorce, but in most cases, mothers are less likely to remarry after the birth of a child and once divorced. And these poor mothers cannot afford to help their children with financial or educational needs. Furthermore, it would mean that these children would be forced to drop out of school to cover their daily allowance, and in some cases be forced to help their mothers who are living in poverty. That means these children don't even get the chance to attend school through the most difficult situations.

\section{Health problem}

The result from study participants shows that lack of access to healthcare services is another negative economic effect of divorce on children. They faced a lack of finance to attend the clinic since it is visible that the majority of children from divorced families live without sufficient and balanced food, unsuitable shelter as well as they do have poor sanitation. Regarding this 17 years old child from divorced families clarified it as:

I don't think I'm completely healthy because I often have a bad bladder that hurts my head and my stomach but I can't get treatment. In fact, I have never been treated on occasion, and my friends have been bothering me with begging and raising money from cafes and suppermarkets. Other than that, I don't have a family that can help and makes me treated because I lost my father after my parents divorced and my mother has no money to help me. But I still need treatment.

It can be understood from the data above; those children who have lost their parents in divorce and living on the street are vulnerable to a variety of minor and serious illnesses. Because these children are less likely to have malnutrition, they are more likely to be exposed to different waterborne diseases as well as diseases due to malnutrition than others. In addition, they can be exposed to colds, while they are exposed to a variety of respiratory and water-borne diseases, and especially if girls are likely to be raped. Thus, even if these children, who are vulnerable to many diseases, are unfortunately ill, most of them do not treat because there are no governmental or non-governmental organizations in the city that can provide and deliver free medical care and treatment including their parents and or families.

More to the point, one key informant described the health situation of children due to the economic effects of their parents' divorce as:

It is clear that children from divorced families are more likely to face health difficulties than children of intact families. Almost all of them are not protected and pursuit by their parents and or families and they are living in the unsecured and unsafe environment as well; the majority of them are exposed to addictions. Thus, they are more vulnerable to and experience different diseases.

Consequently, the above evidence shows that children from divorced families faced a lack of financial access to health-care services and more exposed to different infections. As a result, divorce has a negative economic effect on children's health-care seeing as they are not secured as well as protected well either by their parents and or families or by anybody else.

\section{DISCUSSION AND CONCLUSION}

One of the major concerns of the increase in divorce has been its social effect on children's wellbeing. The result shows that children from divorced families are subject to various forms of the negative social effects of divorce which denies them the right to live and develop fully in a secure environment. Interview findings were similar to Bhukuth's [20] study, where children from divorced families are more likely exposed to child abuse than children who are living in both of their parents. He concluded that after the remarriage of a parent, children are frequently abused and forced to leave the house by the step-father and or step-mother. While the result of this study dependable on the notion that children from divorced families are more vulnerable to different abuses than their counterparts. Furthermore, this finding supported by Rizzini's [21] study, which explained that children from divorced families are exposed to high levels of parental violence, victimization, and sexual harassment. According to Bhukuth [20], children are more exposed to neglect due to parents' separation or divorce. The majority of participants reported that children from divorced families are commonly neglected in society may be by step-parents, relatives, and so on because they are growing up in an unstable nurturing, and poverty. So that they become passive and socially withdrawn, low confidence levels, anxiety, and exhibit frustration and anger than children who are living with both of 
their parents. Since child neglect is the failure to provide for a child's needs and can be physical, emotional, or educational plus it is very common in society and it needs networking to address its negative impact on neglected children (UNICEF). That loss of attachment is one of the major social problems children that have faced due to parents' divorce. In the same way, Williams-Owens [22] asserted that following parents' divorce, children often characterized by loss of either mother's or father's permanent presence and love and because of this stress may take a tremendous toll on the children. Children become attached to their family members such as parents, sisters, brothers, and pets. And the change in contact with any of these people can cause distress, unloved, and so on. Divorce affects the relationship of children with their parents and relatives since they lose their attachment early. Churchill [23] found that the primary social effect of divorce is the declining parent-child relationship; then through time the social competencies of those children have become diminished. More to the point, this study exposed that education and school performance is another chief social effect, a child encountered due to parental divorce. According to Akhtar [24] by viewing the hostile nature of parent's divorce children he or she feels guilty, schoolwork gets affected looked unimportant and school performance worsens. In addition, insecurity was investigated as one major downbeat social effect of divorce on children. Again according to Akhtar children from a divorced family feels insecure and helpless in society, loss their parental love and affection that can't be bought in the market and any places in the world. Hence, the finding of the study revealed that due to their insecurity children from divorced families are highly vulnerable to different risks and problems such as different kinds of abuse, neglect, anxiety, health problems, and so on. In the same way, Olaniyi [25] investigated it as the effect of divorce is the plight of the children. They become the most vulnerable group after divorce since the family which serves as the primary agent of socialization no more exists, this circumstance makes nurturing of children difficult. Prostitutes, delinquents, and other social misfits are normally found to be lots of children from broken homes.

As has been presented in the findings of this study, divorce has mostly a negative effect on children's economic well-being. According to Aster [14], divorce has a serious experience that affects the whole family system through its effect particularly children are the sole victim of it since it damages the economy of the family. However, these big social issues have never been getting attention to find a solution for children who suffered from its negative effect.

Likewise, McLanahan [26] concluded that the economic problem of divorce is serious and has negative impacts on children's wellbeing since security in the economy is essential to be well socially, psychologically, and emotionally. Thus, as it was founded by this study lack of finance to access basic needs is the foremost negative economic effects of divorce the majority of children are encountered. In unfailing to the study finding, Aster [14] inveterate that parental divorced children have faced clothing problems, suffered from food shortages and shelter. Here, findings of the current study discovered that health problem is another major negative economic effect of divorce children is encountered. Regarding this there is compatible research conducted by Braver [27]: Parental divorced children face difficulty to get medical care that the child's medical expenses not covered by insurance. Even though the majority of health problems can be prevented easily, if these children have enough resources and their basic needs are meet. However, they are not lucky due to lack of financial support to health care services either from their parents and or, anybody else.

To sum up, divorce is affecting negatively the social and economic wellbeing of children. The children from divorced families have difficulties in their social life due to their parents' divorce such as low performance in school including school dropout. They are more exposed to child abuse and more vulnerable to child neglect. Because they lose their parent's love, care, protection, and attachment they have difficulties with low self-esteem, they have difficulty sharing opinions, feelings, and ideas as well; they have difficulty making a relationship and they feel insecure. Divorce also has economic problems on children such as unable to get food on time, poor quantity and quality of food, lack of money to cover expenses for clothes, shelter, health, and school types of equipment, is major ones they faced. Thus, children are more likely to be the victim of the negative effects of divorce and they experience socio-economic difficulties as well; they develop anti-social behaviors and more likely to involve in delinquent activities than children from intact families due to a lack of financial and social supports. As a final point, as we know that children are the seeds of society so that to alleviate the problem of divorce governmental institutions and NGO's, families, religious institution, media, schools, and universities play a key role and must give awareness creation about the negative effects of divorce as well; they put the effort much more than they do and perform before.

\section{CONCLUSION}

It is an undeniable fact that the divorce of a couple by and large has a negative impact on everyone involved in the process, including the divorcee, the family members, and the community. However, the results of this study show that the negative effects of divorce on children, in particular, are significant and far-reaching. Sure, the findings of the study indicated that children who lose their parents through divorce are more vulnerable to various problems and suffering than others, but are more vulnerable to social and economic hardship. Looking at the social life of these children; they are more vulnerable to social isolation, abuse and neglect, exploitation, loss of family love, care and attachment, poor academic performance, and various security problems. In addition, according to the results of the study, the economic situation of children is very low and perhaps even worse. All right, these children do not have adequate access to basic necessities such as food, shelter, and clothing, are unable to manage their health due to lack of funds and support and are forced to drop out of school because they do not have the financial means to do so. Divorce is generally a problem that often has serious social and economic consequences for children than others. In addition to the problem, it is a key source of other social problems such as juvenile delinquency, child trafficking, child prostitution, street living, child labour, and so on. Yet, in light of the fact that divorce is a major social problem, various governmental and non-governmental organizations and institutions have not received much attention, and the community and all parties, including parents, need to work harder to reduce and solve it.

\section{REFERENCES}

1. Oxford University Press. Essential English Dictionary. Oxford: Oxford University Press; 1999.

2. Reiners G. Divorce and remarriage in Malawi. Demogr Res 2003;6:175-98.

3. Larsen U, Tilson D. Divorce in Ethiopia. J Biosoc Sci 2000;32:355-72.

4. Fagan PF, Churchill A. The Effects of Divorce on Children. Washington, DC: Marri Marriage and Religious Institutions; 2012.

5. Shibeshi A. Causes of Divorce and its Consequences on Children. A Master Thesis. Addis Ababa, Ethiopia: Addis Ababa University; 2015.

6. Sweet SM. Intergenerational consequences of family disruption. Am J Sociol 2014;94:2

7. De Vaus D, Gray M, Stanton D. The Economic Consequences of Divorce in Six OECD Countries (Research Report No. 31). Melbourne: Australian Institute of Family Studies; 2015.

8. Serkalem B. Divorce: Its Cause and Impact on the Lives of Divorced Women and their Children. A Master Thesis. Addis Ababa, Ethiopia: Addis Ababa University; 2006.

9. Tafesse T. Effects of Traditional Family Arbitration and Legal Divorce on Divorcees and Their Children: The Case of Boloso Sore Wereda, Wolaita Zone, Southern Ethiopia. Addis Ababa, Ethiopia: Addis Ababa University; 2015.

10. Kifle W. Child trafficking, and child migration. J Marriage Fam 2013;50-62.

11. Abebe YM. Lived experience of divorced women in Ethiopia. J Polit Sci Dev 2015;3:268-81

12. Aster S. Causes of Divorce and its Consequences on Children. A Master 
Thesis. Addis Ababa, Ethiopia: Addis Ababa University; 2015.

13. Seid J, Yemataw W. Psycho social and economical consequences of divorce in Muslim community in Gondar city administration. Innov J Soc Sci 2014;2:51-7.

14. Hancock B, Ockleford E, Kate W. An Introduction to Qualitative Research. Leicester: The NIHR Research Design Service for Yorkshire and the Humber; 2007.

15. Stickler U, Hampel R. Qualitative research in CALL. CALICO J 2015;32:380-95.

16. Adhabi E, Anozie CB. Literature review for the type of interview in qualitative research. Int J Educ 2017;9:86-97.

17. United States Agency for International Development. Performance Monitoring and Evaluation TIPS: Conducting Focus Group Interviews. Washington, DC: United States Agency for International Development; 2011

18. Bryman A. Social Research Method. New York: Oxford University Press; 2012

19. Braun V. Thematic Analysis. Vol. 2. Washington, DC: American
Psychological Association; 2012.

20. Bhukuth A, Ballet J. Children of the street: Why are they in the street? How do they live? J Econ Sociol 2015;8:134-48.

21. Rizzini I. Life trajectories of children and adolescents living on the street of Rio de Janeiro. J Child Youth Environ 2003;13:1.

22. Williams-Owens WM. The Behavioral Effects of Divorce can have on Children. New York: The Graduate Center, City University of New York; 2017

23. Churchill PF. The Effects of Divorce on Children. Washington, DC: Marriage and Religion Institute; 2012. p. 2.

24. Akhtar E. Social and economic problems of divorced women. Res Humanit Soc Sci 2016;6:2224-66

25. Olaniyi A. Analytical study of the causal factors of divorce in African. Res Humanit Soc Sci 2015;5:1-13.

26. McLanahan S. Mother-only families: Problems, prospects, and politics. J Marriage Fam 1989;51:557-80.

27. Braver S. The Consequences of Divorce for Parents. Arizona State, USA: Departement of Psychologyand Arizona State University; 2012. 